\title{
Ucrânia: luta pelo direito de escolher seu destino, pela sua soberania e integridade territorial*
}

\section{Ukraine: struggle for the right to choose their destiny, sovereignty and territorial integrity}

\section{Resumo}

Este artigo explora os limites da intervenção russa na Ucrânia a partir de 2014. Retrata a anexação russa da República Autônoma da Criméia e o processo de desintegração territorial que se fez no país desde então.

Palavras-chave: Criméia. Agressão russa. Soberania. Integridade territorial.

\section{Abstract}

This article explores the limits of Russian intervention in Ukraine from 2014. It depicts the Russian annexation of the Crimean Autonomous Republic and territorial disintegration process that was done in the country since then.

Keywords: Crimea. Russian aggression. Sovereignty. Territorial integrity. 


\section{Introdução}

Durante mais de dois anos, a Ucrânia continua a sua luta contra a agressão externa do poderoso país vizinho, que está agredindo nosso estado independente e soberano sob o pretexto de necessidade de proteção de interesses de uma minoria étnica que, aliás, não pediu a ele sobre isso. A Ucrânia defende o seu direito de escolher o seu próprio caminho de desenvolvimento, a sua capacidade de continuar o progresso sustentável do país com base em seu próprio potencial humano e tecnológico.

\section{Ucrânia quer a paz, mas é forçada a lutar}

Como qualquer problema internacional para o qual não se encontra uma solução rápida e que sofre permanentes influências do exterior, a agressão russa contra a Ucrânia e a anexação ilegal da República Autônoma da Criméia tem perdido a atenção de meios de comunicação a despeito das mortes diárias de militares e civis e da continuidade de sofrimento das pessoas que não têm possibilidade de fugir da zona de conflito ou melhorar sua situação nos territórios temporariamente ocupados e controlados pelas autoridades ilegítimas.

A intromissão encoberta da Rússia nos processos democráticos na Ucrânia levou a uma forte deterioração da situação que, em vez de estabilização baseada na busca de caminhos para o entendimento, resultou em uma verdadeira Guerra Híbrida, uma guerra de novo tipo em que participam as unidades regulares de tropas estrangeiras, sem insígnias de identificação, as quais utilizam operações específicas de desinformação e a população civil é usada como escudo humano pelas unidades paramilitares ilegítimas que desesperadamente tentam criar alguma aparência de legitimidade.

As consequências da política agressiva russa surgiram não só para Ucrânia, embora os resultados para nosso país foram as mais graves no sentido das perdas humanas e problemas econômicos.

\section{Direito internacional e garantias}

Como sabemos, os princípios básicos da arquitetura moderna das relações entre os estados no mundo atual têm a sua origem no sistema desenvolvido no período pós-II Guerra Mundial, com a criação da Organi- cisco, documento básico da organização, criada em 1945, apresenta princípios bastante abrangentes. Até fevereiro de 2014, o sistema parecia suficientemente sólido, com mecanismos bastante eficazes para abrir diálogo nos casos de surgimento de conflitos e para manter o equilíbrio na segurança internacional. Criada com fins nobres, a Carta da ONU não conseguiu evitar violações à soberania ucraniana, ameaças a sua integridade territorial e interferências em assuntos internos do país. O mais alarmante é que essas ações foram cometidas por um membro permanente do Conselho de Segurança da ONU - a Rússia -, por meio de coerção política e econômica.

A despeito de suas responsabilidades para a manutenção da paz e segurança junto à comunidade internacional, a Rússia também desrespeitou obrigações definidas nos acordos de Helsinki e no Memorando de Budapeste.

A Conferência de Helsinki, de 1975, visou fixar as fronteiras na Europa. Já o Memorando de Budapeste, de 1994, está ligado à adesão da Ucrânia ao Tratado de Não-Proliferação de Armas Nucleares, buscando estabelecer garantias de segurança contra ameaças ou uso da força contra a integridade territorial ou independência política da Ucrânia. Vale ressaltar que, naquele momento, a Ucrânia era detentora do terceiro maior arsenal de armas nucleares do mundo. Este contingente de armas nucleares adveio da repartição do arsenal soviético à época do desmantelamento da União Soviética. Com a sua boa-fé, a Ucrânia tem uma contribuição significativa para o fortalecimento da paz e da segurança internacional, sendo o primeiro país no mundo a renunciar voluntariamente ao arsenal nuclear poderoso que havia herdado da União Soviética. Além disso, ao longo de mais de duas décadas, a Ucrânia tem sido participante ativa de quase todas as principais missões da paz internacionais.

Assim, com a garantia de proteção por parte dos membros do Conselho de Segurança, a Ucrânia aceitou abrir mão do poder nuclear e consentir a permanência da frota russa no Mar Negro. No entanto, os compromissos assumidos em diferentes épocas não foram traduzidos em respostas imediatas, mediante a aplicação de normas e instrumentos que inibissem as ações agressivas perpetradas pela Rússia a partir do início de 2014.

Todas as decisões desde a reconstituição da sua Independência foram tomadas para realizar o principal objetivo estratégico da Ucrânia: aderir à União Europeia (UE) como um membro de plenos direitos. A este pro- 
pósito estavam subordinados os esforços tanto da política externa como as reformas na política interna e socioeconômica, já implementadas no país. Como grande conquista na integração europeia da Ucrânia, foi recebido pela sociedade o Acordo de Associação com a UE - que, entre outros aspectos, prevê a instalação da Zona de Livre Comércio, que entrou em vigor a partir do dia $1^{\circ}$ de janeiro de 2016.

Infelizmente, neste momento, a Ucrânia é obrigada a adiar os seus sonhos de progresso, de avanços na economia e de desenvolvimento social por causa da agressão terrorista do país vizinho. Através de sua imposição neoimperialista, a Rússia quer privar o povo ucraniano da sua liberdade, soberania e direito de escolha.

\section{História do confronto: ocupação ilegal da Re- pública Autônoma da Criméia}

Desde novembro de 2013 até fevereiro de 2014, na Ucrânia aconteceram protestos da sociedade civil contra a decisão do então governo de se recusar ao curso pró-europeu que, em sequência, evoluíram em fortes protestos contra a corrupção, repressão, ditadura e violação dos direitos humanos. Os protestos terminaram com a deposição do ex-presidente Viktor Yanukovych em 22 de fevereiro de 2014 e são conhecidos como a Revolução da Dignidade ou Euromaidan ${ }^{2}$.

Ainda antes do desfecho trágico dos protestos em Kyiv, já no dia 20 de fevereiro de 2014, a Rússia iniciou uma agressão armada contra a Ucrânia realizando a ocupação ilegal da República Autônoma da Criméia e da cidade de Sebastópol. Apesar de o governo russo, na época, recusar a presença das tropas russas, um ano mais tarde o próprio presidente Vladimir Putin reconheceu a participação dos militares russos na tomada dos prédios do governo de Criméia e bloqueios das bases do exército ucraniano. Ainda mais tarde, ele também informou que, na época, estava pronto para usar as armas nucleares contra a Ucrânia em caso de resistência.

Deste jeito, Moscou usou sua vantagem incomparável em força militar e seu estatuto nuclear, violando as

2 Recomendo vivamente aos interessados de aprofundar o seu conhecimento sobre esses acontecimentos o documentário "Winter in fire. Ukraine's fight for freedom" no Netflix brasileiro. O documentário foi um dos cinco candidatos ao Prêmio Oscar no 2016 garantias dadas à Ucrânia no ano 1994 pelo Memorando de Budapeste, assim como violando o Tratado Bilateral de Amizade e Cooperação, assinado em 1997.

Como resultado desta operação militar, o governo legítimo da República Autônoma da Criméia foi brutalmente retirado do poder e um homem com antecedentes criminais foi instalado como primeiro-ministro. A junta criminosa, no dia 16 de março de 2014, realizou um «referendo», que foi uma farsa política orquestrada pela Federação Russa, representando uma violação das leis internacionais fundamentais.

A maioria dos observadores que participaram desta farsa representavam as forças marginais da esquerda e da direita. Especialmente foi marcante a participação de neonazistas da Europa e políticos profundamente antissemitas.

Nem a Ucrânia, nem a comunidade internacional, reconheceram essa farsa de plebiscito. No dia 27 de março de 2014 foi aprovada a Resolução 68/262 da Assembleia Geral das Nações Unidas que reiterou o compromisso com respeito à integridade territorial da Ucrânia dentro de suas fronteiras internacionalmente reconhecidas $\mathrm{e}$ sublinhou a nulidade do referendo da Criméia ${ }^{3}$. A resolução foi apoiada por 100 membros das Nações Unidas. 11 países (Armênia, Bielorrússia, Bolívia, Cuba, Coréia do Norte, Nicarágua, Rússia, Sudão, Síria, Venezuela e Zimbabwe) votaram contra a resolução. Houve 58 abstenções, e outros 24 Estados não participaram na votação. O Brasil se absteve.

O silêncio absoluto, constrangedor e dramático do Brasil diante da anexação russa da Crimeia e da agressão russa no leste da Ucrânia é uma violação direta e óbvia do princípio de autodeterminação dos povos e não intervenção nos assuntos internos de outros países, definido na Constituição brasileira. Uma violação que é justificada pela política externa brasileira em nome das alianças de pólos Sul-Sul, que visam a enfraquecer os centros tradicionais de poder ${ }^{4}$

A anexação ilegal da República Autônoma da Criméia pela Rússia provocou violações significativas dos di-

3 Cf. Disponível em: <http://mfa.gov.ua/ua/press-center/briefing/1211-brifing-v-mzs>. Acesso em: 7 mar. 2015.

4 Demetrio Martinelli Magnoli, Sociólogo e Comentarista de Política Internacional da Globo News durante o discurso no Seminário: Rumos da Política Externa Brasileira, realizado no dia 10 de dezembro de 2014 na Comissão de Relações Exteriores e de Defesa Nacional da Câmara dos Deputados do Congresso Nacional do Brasil. 
reitos humanos. A ONU, a OSCE, o Conselho da Europa e outras organizações internacionais continuam a chamar a atenção para os inúmeros casos de violação dos direitos humanos dos Tártaros da Criméia.

Os Tártaros da Criméia tornaram-se alvos de desaparecimentos forçados e raptos cometidos pelas autoridades de ocupação russas e suas gangues. Como resultado das políticas de ocupação da Rússia, mais de 20 mil Tártaros da Crimeia foram obrigados a deixar a sua terra natal, sua vida, sua identidade e sua história. É proibida a entrada na Criméia dos líderes da comunidade dos Tártaros da Criméia - Mustafa Jemilev e Rafat Chubarov. O organismo da representação do povo tártaro de Criméia - Mejlis - foi banido na península temporariamente ocupada. Até as homenagens às vítimas da deportação do povo Tártaro de Criméia em 1944 estão proibidas na Rússia.

A Rússia anexou a Criméia, sob o pretexto de restaurar a "justiça histórica" e "de reunificar as terras russas”. Estas noções não existem no Direito Internacional. Neste contexto, surge a questão da veracidade de tais suposições porque se olharmos para a história desta rica região, os "direitos históricos" podem reclamar mais de uma dúzia de nações e povos 5 .

Os primeiros habitantes da península da Criméia foram as tribos de cimeiros, citas e tauros, os últimos deram o nome desta terra - Tavrida. Aproximadamente no século VI antes de Cristo, na costa, apareceram cidades gregas. Os gregos trouxeram para a península sua cultura e artesanato avançado, começaram a construir templos e estádios e desenvolveram o comércio e a agricultura ${ }^{6}$. Mais tarde, no século I A.C., a Criméia passou para o controle do Império Romano.

Em meados do século XV, na península da Criméia, Tártaros criaram o Canato da Criméia que, no ano de 1475, passou para o protetorado do Império Otomano. Durante três séculos, o Canato da Crimeia foi o estado mais poderoso na região, que atemorizava os seus vizinhos. Em particular, em 1571, Khan da Criméia apoderou-se da metade do estado Moscovita e queimou a cidade de Moscou. Portanto, até o final do século XVII, Moscou foi obrigada a pagar o tributo ao Canato de Cri-

5 Cf. Disponível em: <http://obozrevatel.com/politics/ 93174-istoriya-kryima-chej-na-samom-dele-poluostrov. htm>. Acesso em: 3 mar. 2015. méia ${ }^{7}$. No século XVIII, o Império Otomano entrou em declínio e depois de inúmeras guerras em 1783, a Criméia foi anexada ao Império Russo. A costa do Sul, graças a seu clima único, tornou-se um destino de férias preferido dos tzares e dos imperadores russos.

No intervalo de 1918-1921, a Criméia foi o centro de uma guerra civil e de redistribuição de poder. Esses turbulentos anos terminaram em 1922 com a inclusão da Criméia na União Soviética, com a formação da Autônoma República Socialista Soviética da Criméia como parte da Federação Russa.

Durante a Segunda Guerra Mundial, mais especificamente no outono de 1941, a Criméia foi ocupada pela Alemanha e, em maio de 1944, liberada pelas tropas soviéticas. A partir desta data, começou a deportação em massa para Ásia Central e a Sibéria com o confisco de todos os bens dos Tártaros da Criméia, Armênios, Gregos, Alemães e Búlgaros, que viviam na península e foram reconhecidos pelos soviéticos como "não confiáveis", e não leais às autoridades. Foram deportadas quase 300 mil pessoas, dentre os quais, cerca de 200000 eram Tártaros da Criméia. O retorno em massa dos Tártaros da Criméia para sua terra começou apenas no final da década de $1980^{8}$.

Um importante marco na história moderna da Criméia foi o dia de 19 de fevereiro de 1954, quando o Presidium (Mesa Diretiva) do Soviét Supremo (Parlamento) da URSS, com seu Decreto, passou a Região da Criméia da Federação Russa à República Socialista Soviética da Ucrânia ${ }^{9}$ com a observância de todos os procedimentos legais vigentes naquela época. O Decreto apontou que, dada a generalidade da economia, proximidade territorial e vínculos estreitos econômicos e culturais entre a Crimeia e a Ucrânia, esta região seria transmitida para composição da RSS da Ucrânia.

A decisão foi razoável e economicamente plausível, mas a Ucrânia recebeu uma região com a economia destruída e com escassez grave de mão de obra.

A Segunda Guerra Mundial causou danos significativos à Criméia e a deportação de populações autóctones levou à redução de habitantes da península de 780

Cf. Disponível em: <http://www.mtss.ru/?page=tyish >. Acesso em: 3 mar. 2015.

8 Cf. Disponível em: <http://ru.krymr.com/content/article/26779236.html $>$. Acesso em: 4 mar. 2015.

9 Ведомости Верховного Совета СССР. n. 4, p. 798, 9 mar. 1954. 
mil até 500 mil pessoas. Esses fatores induziram a região a uma situação catastrófica do ponto de vista econômico e social. A indústria agrícola, especialmente, sofreu a pior $\operatorname{perda}^{10}$.

Para compensar a escassez de força de trabalho, começaram a chegar à Criméia migrantes de outras partes da União Soviética e, em particular, do Norte da Rússia, motivados pela promessa de clima bom e a terra fértil.

Como resultado da guerra e da deportação, a terra de outrora fértil se transformou em uma região depressiva. Em um estado de abandono estavam os setores chave da indústria e da economia da Criméia na época: a pecuária, a jardinagem, a enologia e a viticultura ${ }^{11}$. Notórios são os seguintes números: no final de 1953, em toda Criméia, havia apenas 3 lojas de padaria, 18 lojas de carne, 8 de produtos lácteos, 2 de tecidos, 9 de sapatos, 5 de materiais de construção e 28 livrarias $^{12}$. A região dos estepes da Criméia sofria de considerável falta de água.

Assim, em vez de "presente", a Ucrânia recebeu uma região problemática, que foi obrigada a se reconstruir.

Um dos pretextos de adesão da Criméia à Ucrânia foi a construção do canal do Norte da Criméia com o objetivo de resolver o problema de escassez de água e de irrigação de terras da região dos estepes da Criméia com as águas do Rio ucraniano de Dnipró. A gerência e execução do projeto foram realizadas pela Ucrânia.

Em 1955, começou a construção desta estrutura gigante de irrigação no sul da Ucrânia. O comprimento total do canal é de mais de 600 quilômetros. Já na primeira década após da inclusão da Criméia na composição da Ucrânia começou o crescimento econômico da península em quase todos os setores. Da Ucrânia foi fornecido o gás, a eletricidade e a água. Na península apareceu a linha de trólebus cruzando os morros, houve um aumento importante da produção industrial e agrícola e começou o desenvolvimento da construção civil e de infraestrutura turística. Naquela época. foram construídas 76 grandes empresas industriais ${ }^{13}$. Começaram a ser construídas

10 Cf. Disponível em: <http://www.istpravda.com.ua/articles/2011/02/21/26135/>. Acesso em: 4 mar. 2015.

11 Cf. Disponível em: <http://www.istpravda.com.ua/articles/2011/02/21/26135/>. Acesso em: 4 mar. 2015.

12 Cf. Disponível em: <http://www.istpravda.com.ua/articles/2011/02/21/26135/>. Acesso em: 4 mar. 2015.

13 Социалистическое народное хозяйство Крымской области (1945-1970). Симферополь, 1980. pousadas e acampamentos, para os quais as crianças de todas as repúblicas da ex-URSS e do exterior passavam as suas férias de verão.

Assim, a Ucrânia fez uma contribuição inestimável para o desenvolvimento e fortalecimento da República Autônoma da Criméia, que se tornou uma parte integrante do território e da cultura ucraniano.

Após o colapso da União Soviética e a proclamação da independência da Ucrânia, a Frota Soviética do Mar Negro foi dividida entre a Ucrânia e a Rússia. Depois de longas negociações pelo Acordo de 9 de junho de 1995, 18,3\% dos navios passaram para a Ucrânia, e de $81,7 \%$ - para a Rússia. Bases navais de Izmayil, Odessa, Ochakiv, Kerch, Donuzlav e Balaclava e mais de 10 bases de aviação marítima ficaram sob o controle das forças navais da Ucrânia.

Apesar do fato de a Constituição da Ucrânia de 1996 proibir o deslocamento em território ucraniano de quaisquer formações militares estrangeiras, no ano de 1997, foi assinado um Acordo sobre os parâmetros do repartimento da Frota do Mar Negro, que determinou o prazo de permanência da frota Russa em Sebastópol até 2017, e que determinou o preço de aluguel da base militar pela Rússia em cerca de 97 milhões de dólares por ano.

A permanência da base naval da Frota do Mar Negro da Rússia em Sebastópol, periodicamente, causava tensão entre a Ucrânia e a Rússia e tornou-se um dos principais fatores de suas reivindicações sobre a Crimeia. Durante os anos 2005-2010, a parte russa repetidamente levantava a questão da necessidade de retirada da Frota do Mar Negro de Sebastópol após a expiração do prazo de vigência do Acordo em 2017, usando este assunto como fator desestabilizador das relações ucraniano-russas.

No entanto, o ex-Presidente da Ucrânia Viktor Yanukovich, que teve uma política da aproximação perigosa com a Federação Russa, em 2010, decidiu prorrogar o prazo da permanência da Frota russa até 2042, com a opção de outra prorrogação até mais 5 anos. Da sua parte, a Rússia obrigou-se oferecer $30 \%$ de desconto no preço do gás fornecido à Ucrânia.

Este negócio recebeu uma avaliação contraditória da parte de políticos e cidadãos ucranianos, que achavam a possibilidade de estender a estadia da Frota do Mar Negro da Federação Russa como uma chantagem cujo preço era alto demais por reduzir o custo de importação de gás russo. Como mostrou a história, essa crítica foi certa e dependência perigosa da Rússia do ex-Presidente Yanu- 
kovych levou a consequências desastrosas - a anexação ilegal da República Autônoma da Criméia.

A proporção total da Criméia e de Sebastópol no PIB da Ucrânia era de aproximadamente 3\%. O PIB da Criméia foi estimado em 4,3 bilhões de dólares de EUA em 2012. A base econômica da Criméia é o setor de serviços, especialmente o turismo (cerca de 60\%), indústria $(16 \%)$, comércio $(13 \%)$ e agricultura $(10 \%)^{14}$. As principais indústrias da Criméia são de processamento, de alimentos e química, comércio, transporte e comunicações, bem como as operações imobiliárias.

Falando sobre o desenvolvimento econômico da Criméia, podemos usar as estatísticas recolhidas antes da agressão russa. De acordo com os dados do ano 2013, grande parte dos bens de exportação da península foi enviada para os países da Comunidade dos Estados Independentes (cerca de $40 \%$ ), incluindo a Rússia (26,1\%) e um pouco menos para os países da União Europeia $(19 \%)^{15}$. No total, as empresas da Criméia exportaram a soma de 915 milhões de dólares, cerca de 1,4\% da exportação da Ucrânia (a população da Criméia é de cerca de 2 milhões de pessoas, ou $4,3 \%$ da população da Ucrânia) ${ }^{16}$. Bens básicos de exportação da região eram os de produção da indústria química, produtos minerais, petróleo e produtos de sua destilação, maquinaria, além de produtos agrícolas.

As maiores empresas da Criméia, famosas por seus produtos em vários países do mundo, são "Novyi svit" e "Massandra" com famosas marcas de vinho de excelência.

No seu território, a Criméia tem mais de 11. 500 monumentos culturais e de arquitetura, pertencentes a diferentes períodos históricos, civilizações, grupos étnicos e religiões ${ }^{17}$. Graças aos ricos recursos culturais, ao clima agradável e à proximidade ao mar, a indústria do turismo é tradicionalmente dominante dentre as outras atividades. Anualmente a Criméia era visitada por aproximadamente 6 milhões de turistas, principalmente da parte continental da Ucrânia, Rússia, Bielorrússia e de outros países vizinhos.

14 Cf. <http://www.krimspec.org/economica/sovremensostoyan /377-sovremensostoyani-prognozrazvitiya18.html>. Acesso em: 8 mar. 2015.

15 Cf. Disponível em: <http://gosstat.crimea.ru/ukgvesi.php\#_ geoi>. Acesso em: 6 mar. 2015.

16 Cf. Disponível em: <http://finance.liga.net/economics/2014/ 3/5/articles/37664.htm> . Acesso em: 8 mar. 2015
No entanto, o turismo na Criméia, por sua sazonalidade e seu caráter informal, não trouxe ganhos elevados e representa apenas cerca de $6 \%$ da estrutura de renda da península ${ }^{18}$.

Nos períodos de baixa temporada, que dura na Criméia de novembro até abril, sempre houve um problema de desemprego oculto. Além disso, a maior parte da receita do turismo é informal, porque o setor privado sempre esteve interessado em trabalhar sem pagamento de impostos.

Deve-se notar que, em geral, Criméia sempre dependia das dotações orçamentárias que formavam cerca de $66 \%$ dos seus gastos ${ }^{19}$.

De acordo com a Tesouraria Estatal da Ucrânia, no ano de 2013, subsídios diretos para a Criméia totalizaram 116,7 milhões de hryvna (aproximadamente 14,6 milhões de dólares). Anualmente, o orçamento estatal da Ucrânia eviaava cerca de cerca de 3 bilhões de hryvna (aproximadamente 375 milhões de dólares EUA) à Criméia $^{20}$. Além de subsídios financeiros, a Criméia depende em $80 \%$ do fornecimento da Ucrânia de água potável e de água para irrigação e de $85 \%$ de energia elétrica, tendo em vista que só $15 \%$ das necessidades de energia são cobertas pela produção local de centrais térmicas, solares e eólicas. Ademais, $100 \%$ da rede de internet e de comunicação telefônica são fornecidas pela Ucrânia ${ }^{21}$.

O rompimento de laços estreitos com a Ucrânia como o resultado da anexação da Criméia pela Rússia em março de 2014 levou ao atual declínio do sistema econômico da região.

\section{Agressão contínua em Donbass}

Os confrontos violentos na região de Donbass começaram em meados de abril de 2014, quando grupos armados de ativistas pró-russos ocuparam os edifícios públicos e departamentos de polícia nas cidades de Donbass (em particular, Sloviansk, Artemivsk e Kramatorsk). Para

18 Cf. Disponível em: <http://www.bbc.co.uk/russian/international/2014/02/140228_crimea_economy_questions_ answers $>$. Acesso em: 6 mar. 2015.

19 Cf. Disponível em: <http://tyzhden.ua/News/103273>. Acesso em: 6 mar. 2015.

20 Cf. Disponível em: <http://www.treasury.gov.ua/main/uk/ doccatalog/list?currDir=212666> . Acesso em: 7 mar. 2015.

21 Cf. Disponível em: <http://www.slovoidilo.ua/articles/8017 /2015-03-03/zavisimost-kryma-ot-materikovoj-ukrainy-infografika.html>. Acesso em: 7 mar. 2015. 
acabar com as atividades ilegais de grupos armados, que criaram perigo real para grandes grupos da população, o governo ucraniano foi obrigado a realizar a Operação Antiterrorista, com a participação das Forças Armadas. Gradualmente, os confrontos se transformaram em um grande conflito militar.

As ocupações em massa de edifícios públicos e as ações de sabotagem na região de Donetsk foram coordenadas pela inteligência das Forças Armadas da Federação Russa que não só forneceu armas, mas diretamente ajudou aos assim chamados separatistas e marginais a desestabilizar a região.

As autoridades russas repetidamente declararam a sua rejeição da Operação Antiterrorista, exigiram a sua cessação e o início de negociações com os separatistas.

Apesar de inúmeras evidências da presença de tropas russas no território da Ucrânia, oficialmente, a Rússia não reconhece o fato de sua invasão na Ucrânia, portanto, a guerra é considerada como não declarada. $\mathrm{O}$ confronto armado no leste da Ucrânia tem todas as características da Guerra Híbrida, cuja doutrina muda o que se conhece sobre como fazer e prevenir a guerra. Uma guerra estranha, com caraterísticas de combate convencional e irregular em um mesmo teatro de operações, contra um inimigo bem armado e treinado, com participação de nacionais e de combatentes voluntários e militares regulares estrangeiros especializados, que contam com apoio financeiro encoberto, além de inteligência militar vinda do exterior.

O episódio mais trágico da crise ocorreu no dia 17 de julho de 2014, quando um avião comercial da Malaysia Airlines que ia de Amsterdã, na Holanda, para Kuala Lumpur, na Malásia, foi abatido por um míssil disparado a partir da região tomada por separatistas do sistema de mísseis "Buk" russo. Todas as 298 pessoas a bordo morreram.

O líder dos terroristas Igor Girkin (Strelkov) imediatamente comentou sobre a catástrofe do avião, acreditando que se tratava de um avião ucraniano que foi abatido: "Em Torez um An-26 foi derrubado, seus estilhaços estão em algum lugar perto da mina de carvão "Progress". Nós avisamos a todos: Não voem em nosso céu ${ }^{22 ” . ~ L o g o ~}$

22 Fonte: Reportagem da Revista Exame de 17/07/2014: Disponível em: <http://exame.abril.com.br/mundo/noticias/ucrania-acusa-russia-de-derrubar-aviao-da-malaysia-airlines $>$. Acesso em: 13 abr. 2015. depois de entender que foi o avião de passageiros, os terroristas começaram a negar seu envolvimento na tragédia de escala mundial, culpando os militares ucranianos.

Segundo os dados oficiais da ONU, desde o início da agressão, 9 mil 371 cidadãos ucranianos foram mortos e 21.523 feridos. Já nos primeiros meses do ano 2016, as posições ucranianas têm sido bombardeadas mais de 2500 vezes, deixando dezenas de soldados ucranianos mortos e mais de 150 feridos.

Durante agressão sob o comando de oficiais russos em Donbass, foi criado um exército ilegal de quarenta mil membros, equipado e financiado pela Rússia. Este exército está equipado com os armamentos modernos russos: artilharia pesada e lançadores múltiplos de foguetes BM-21 Grad, Tornado e TOS-1 Buratino, dispositivos de comunicação criptográfica e monitoramento (complexos eletrônicos militares Rtut-BM, Shipovnik-Aero, Leyer-2, 1RD257 Krasukha-4), sistemas de defesa antiaérea Buk (SA-11 Gadfly), Strela (SA-13 Gopher), Pantzyr (SA-22 Greyhound). Agora, este exército separatista tem cerca de 470 tanques, 870 veículos blindados de transporte de pessoal, 450 sistemas de artilharia, 190 lançadores múltiplos de foguetes. A Rússia também utiliza tais tipos de armas proibidas, como bombas de fragmentação (9M55K) e minas antipessoais (PMN-2, MON-50).

Apesar disso, a Ucrânia consistentemente cumpre suas obrigações na área de segurança, política, socioeconômica e humanitária, estipuladas nos Acordos de Minsk de 5 de setembro de 2014 e de 11 de fevereiro de 2015. Em particular, o frágil cessar fogo garantiu o acesso total para o pessoal da Missão Especial de Monitoramento da Organização para a Segurança e Cooperação na Europa (OSCE) nos territórios sob seu controle perto da linha de contato. A delegação ucraniana no Grupo de Contato Trilateral apresentou sua visão sobre as modalidades de eleições locais em determinadas áreas de Donbass com base em Acordos de Minsk, padrões internacionais e as leis da Ucrânia. A Ucrânia deu passos importantes no sentido da solução política do conflito, aprovando em Parlamento, em primeira leitura, o projeto de lei sobre alterações da Constituição da Ucrânia.

O Governo Ucraniano não interrompeu o fornecimento de gás natural e de eletricidade para as áreas controladas pela guerrilha, nem o pagamento das pensões e outros benefícios sociais para os cidadãos da Ucrânia nos territórios temporariamente ocupados de Donbass. Permanecendo sob bombardeios constantes, os especialistas 
ucranianos estão reparando a infraestrutura, gasodutos e linhas de energia para garantir as necessidades da população civil.

A Rússia não cumpriu nenhuma das suas obrigações previstas nos Acordos de Minsk. A Rússia e os militantes controlados pela mesma continuam com suas provocações mediante o uso de armas que deveriam ter sido removidas sob a supervisão e monitoramento da OSCE - lançadores múltiplos de foguetes, artilharia autopropulsora, morteiros de calibre $82 \mathrm{~mm}$ e $120 \mathrm{~mm}$. As tropas russas em Donbass continuam a realizar irrestritamente rotações, formação e fornecimentos através das zonas descontroladas da fronteira da Ucrânia.

Até agora, a Missão de Monitoramento Especial da OSCE não teve o acesso completo, seguro e livre para todas as áreas controladas pela Rússia e seus militantes. Nenhum progresso foi conseguido para o acesso da OSCE à fronteira e nem para o estabelecimento de uma zona de segurança, tal como está previsto pelos Acordos de Minsk, para terminar e impedir o fluxo de armas e tropas russas para a Ucrânia.

A Rússia e seus fantoches impedem permanentemente a liberação de reféns ucranianos, mantendo-os em condições desumanas, submetendo-os às torturas e ameaçado-os com a pena de morte, na base do Código Penal da URSS.

A Rússia continua as perseguições políticas dos cidadãos da Ucrânia e se recusa a liberar mais de 130 presos políticos ucranianos detidos ilegalmente na Rússia. A libertação da piloto ucraniana Nadiya Savchenko em 25 de maio de 2016, como resultado da troca por dois militares russos do Departamento Central de Inteligência (GRU) detidos e condenados na Ucrânia foi mais um fato de reconhecimento pela Rússia da participaçao das suas tropas na guerra contra Ucrânia. Nadiya Savchenko, deputada da Verkhovna Rada e da Assembleia Parlamentar do Conselho da Europa, durante seu recluso arbitrário na Rússia, converteu-se em um símbolo de resistência e luta da solidariedade internacional com a Ucrânia.

A Rússia e os militantes apoiados por ela estão bloqueando a entrega de ajuda humanitária ucraniana e internacional para a população civil e sistematicamente impedem as atividades das organizações humanitárias internacionais, incluindo a Cruz Vermelha.

A Ucrânia apela a todos os Estados membros da ONU para exigir da Federação Russa o cumprimento de todos os seus compromissos de acordo com a Carta das
Nações Unidas e com o Direito Internacional, a plena implementação dos Acordos de Minsk e a cessação imediata de todos os atos de agressão contra a Ucrânia.

Apelamos à comunidade internacional para exercer a máxima pressão sobre a Rússia e manter as sanções até que o Donbass e a Criméia estejam desocupados e a integridade territorial e soberania da Ucrânia sejam restauradas.

\section{Direitos Humanos}

Devido à falta de vontade da parte russa e dos separatistas por ela apoiados para restaurar a paz, a situação no leste da Ucrânia permanece instável e continua a afetar seriamente os direitos humanos, especialmente daqueles que vivem perto da linha de contato e em áreas que são controladas por grupos armados.

No dia 3 de junho, o Escritório do Alto Comissariado das Nações Unidas para os Direitos Humanos (ACNUDH) publicou o seu $14^{\circ}$ relatório sobre a situação dos direitos humanos na Ucrânia. O documento se baseia nos resultados do trabalho da Missão de Observação das Nações Unidas na Ucrânia durante o período de 16 fevereiro a 15 maio de 2016.

O $14^{\circ}$ relatório do ACNUDH confirma mais uma vez o "fluxo transfronteiriço a partir do território da Federação Russa dos militantes estrangeiros, incluindo cidadãos da Federação Russa, munições e armas pesadas”. A Missão documentou os crimes em massa cometidos contra os nossos cidadãos pelas autoridades de ocupação russas na Criméia e pelos militares russos e seus cúmplices em Donbass. Mais uma vez, foi constatada a persistência de práticas criminosas de assassinatos de civis, sequestros, torturas, violência sexual, trabalho forçado, extorsão e outras violações dos direitos humanos, as quais os cidadãos ucranianos sofrem todos os dias.

Apresentando o relatório na cidade de Kyiv, o Secretário-Geral para os Direitos Humanos Ivan Shimonovic disse que o principal pré-requisito para eleições locais no território de certos distritos das regiões de Donetsk e Lugansk é restaurar os direitos políticos e civis dos residentes locais.

A Ucrânia apóia essa posição do ACNUDH e convida a comunidade internacional a aumentar a pressão sobre a Federação Russa para terminar imediatamente o apoio às assim definidas pelo Parlamento ucraniano 
como organizações terroristas: "República Popular de Donetsk" e "República Popular de Luhansk".

A Ucrânia compartilha a conclusão do relatório sobre atualidade dos Acordos de Minsk e a importância da sua aplicação para acabar com as violações em massa dos direitos humanos.

A situação na Criméia ocupada permanece extremamente difícil, especialmente considerando a proibição de Mejlis e, em seguida, o fortalecimento da onda de perseguições. Sequestros, buscas, prisões ilegais, espancamentos, restrições à liberdade de expressão e de reunião, bem como outros direitos civis básicos tornaram-se comuns na península.

Mais uma vez, a Ucrânia exige que as autoridades de ocupação da Federação Russa, a quem também se dirige o ACNUDH nas suas recomendações, assegurem o acesso à península das missões internacionais de monitoramento dos direitos humanos, cancelem a decisão da proibição de Mejlis do Povo Tártaro da Criméia, realizem investigações de todas as alegações de maus-tratos, torturas, sequestros, desaparecimentos, identifiquem e assegurem a punição dos responsáveis.

A posição da Ucrânia permanece inalterada: todas as violações dos direitos humanos, independentemente do seu autor e do local onde foram cometidos, não devem ser impunes. Neste sentido, agradecemos a atenção da Missão às comunicações sobre possíveis abusos e violações por parte das agências da Ucrânia, e estudamos cuidadosamente as recomendações. Deve-se notar que ACNUDH não ignora os esforços do Governo da Ucrânia para o julgamento dos culpáveis em violação dos direitos humanos.

O relatório também avaliou positivamente as reformas em grande escala e destacou a formação de um campo jurídico-legal na Ucrânia.

A Ucrânia sempre considerou o trabalho da Missão dos Direitos Humanos das Nações Unidas como uma parte importante na luta contra a agressão russa e um instrumento eficaz para a documentação das violações dos direitos humanos pelas autoridades de ocupação na Criméia e dos crimes do exército russo e dos grupos armados ilegais em certos distritos das regiões de Donetsk e Lugansk.

A parte ucraniana espera que a comunidade internacional intensifique a pressão sobre a Federação Russa com a finalidade de cessação imediata dos atos de agressão contra o nosso Estado, retirada das forças armadas da Federação Russa do território da Ucrânia, término do fornecimento de armas e de equipamentos militares aos mercenários de organizações terroristas, cancelamento de qualquer ato destinado a legalização da anexação ilegal da Criméia e sua completa desocupação.

\section{A guerra informática como parte da Guerra Híbrida}

Existem também as consequências da presente agressão russa contra a Ucrânia que são difíceis de medir e estão provocadas pela guerra de informação, ou melhor, desinformação. Para entender o efeito que produz a guerra russa de desinformação temos de entender o tamanho da potência do aparelho propagandístico russo, que mecanismos usa e que resultados consegue atingir.

O governo russo considera a comunicação como um campo de batalha vital da sua política externa, preparando-se para sair vencedor na eventual Terceira Guerra Mundial. O Kremlin desenvolveu um extenso arsenal de mídia bem financiado para projetar sua imagem desejada para o público, tanto na Rússia como no estrangeiro. No seu território, o Estado russo tem o controle completo sobre as notícias que são divulgadas em todos os canais de televisão, assim como goza da lealdade completa da mídia impressa, rádio, sites de notícias e agências. Fontes de notícias alternativas que apresentam diversos pontos de vista estão disponíveis na Rússia, mas eles têm sido marginalizados de forma eficaz.

A Rússia apresenta gastos muito altos para a sua propaganda e, durante os anos do governo do Vladimir Putin, desenvolveu uma rede extensa dos meios de comunicação no exterior. Segundo os cálculos, os gastos do governo russo para esses fins, em 2014, foram por volta dos 1,6 bilhões de dólares. O canal Russia Today tem um dos maiores orçamentos comparado com os canais de mídia internacional - o orçamento anual do canal é de $275 \mathrm{mi}$ lhões de dólares. Para efeito de comparação, o Euronews só tem 15 milhões de dólares.

Pesquisas de opinião pública russa indicam invariavelmente a ligação entre a apresentação das notícias internacionais e as percepções dominantes na sociedade. Os jornalistas dos meios de comunicação estatais russos agora falam abertamente sobre o papel da sua propaganda: eles afirmam estar lutando por seus interesses nacionais em resposta à mídia ocidental que faz o mesmo.

Os meios de comunicação estatais russas têm audiência e influência importante nos países pós-soviéticos, 
especialmente na parte da população que ainda fala russo. Por exemplo, a maioria da população da Bielorrússia assiste as notícias da TV russa e, como resultado no país, observa-se o maior apoio da política externa russa. Na Ucrânia, uma pesquisa nacional recente que excluía a Criméia, constatou que 9 por cento dos respondentes continuavam vendo a televisão russa "regularmente", apesar de uma proibição pelo governo de transmissão de televisão russa a cabo, e outros 29 por cento assistem "de vez em quando". A influência da mídia russa tem sido amplamente responsabilizada por alimentar o movimento separatista no sul e no leste da Ucrânia desde o início da crise.

Um acontecimento muito demonstrativo de propaganda russa em ação foi o caso do vôo MH17 da Malaysia Airlines, abatido sobre o território da Ucrânia, com 283 passageiros e 15 tripulantes vitimados, de cidadanias holandesa, malaia, norte-americana, sul-africana e britânica. Enquanto os investigadores internacionais tentaram reunir as evidências de como o vôo $\mathrm{MH} 17$ foi abatido, rumores espalharam-se por toda a Internet. De acordo com uma das primeiras versões russas, as forças do governo ucraniano abateram o avião de passageiros civil, acreditando que era o avião do presidente russo Vladimir Putin. Outra história reivindicou que o avião tinha sido preenchido com cadáveres, e quando sobrevoava a zona de conflito na Ucrânia, os explosivos foram detonados.

Teorias mais sóbrias, com base em evidências de que o avião fora destruído por um míssil terra-ar de fabricação russa lançado por separatistas pró-russos, foram desmentidas por Moscou que, por sua sua vez, culpou os militares ucranianos.

Alguns dos métodos utilizados são tradicionais, incluindo desinformação, "meia verdade" e etiquetagem, mas a guerra atual está sendo conduzida com uma variedade de armas modernas, incluindo mídia eletrônica, comunicações digitais, blogs e meios de comunicação social. "Anteriormente, havia preparação de artilharia antes de um ataque," disse o apresentador de televisão russa e chefe da agência de informação do governo Russia Today - Dmitry Kiselev. “Agora, é a preparação de informação.”

A primeira mentira na guerra da Rússia contra a Ucrânia apareceu no final de fevereiro de 2014, quando os homens em camuflagem verde militar, portando armas, tomaram posições na República Autônoma da Criméia. Apesar das indicações de que os homens eram for- repórteres em uma entrevista coletiva em 4 de março: “o espaço pós-soviético está cheio de tais uniformes", e qualquer um poderia tê-los comprado. Mais tarde, no entanto, declarou que nunca tinha escondido que as tropas russas estavam presentes na Criméia. "Claro, militares russos apoiaram as forças de autodefesa da Criméia”, disse ele, mas insistiu que "eles eram necessários para proteger a vida dos moradores da Criméia que falam russo".

Assim, "a salvação de vida dos russos e das pessoas que falam russo dos fascistas" (como a propaganda russa etiquetou os ucranianos) tornou-se o pretexto para justificar a ocupação da Criméia pelo Kremlin e a mensagem se transmitia constantemente em todos os meios de comunicação estatais da Rússia, especialmente a televisão, que atinge mais de $90 \%$ da população.

Mas a campanha contra a Ucrânia começou ainda antes, com os protestos na cidade de Kyiv contra o governo corrupto do ex-presidente pró-russo Viktor Yanukovich. Em particular, na época, os meios de comunicação controlados pela Federação Russa apresentavam um universo paralelo enquanto a "crise humanitária" se desenrolava. Ucranianos de língua russa estavam sob ataque. Centenas de milhares de pessoas fugiam do país - uma alegação que mais tarde se mostrou falsa. Os participantes dos protestos nas ruas de Kyiv foram apresentados como "radicais", "extremistas" e "nacionalistas". A TV estatal russa estava cheia de imagens de suásticas e derramamento de sangue, semeando pânico porque "a sangrenta batalha contra o fascismo de meio século atrás estava de volta novamente".

O Departamento de Estado dos EUA, na época, em uma declaração, prestou atenção que "a máquina de propaganda russa continuava a promover o discurso de ódio e incitar a violência através da criação de uma falsa ameaça na Ucrânia que não existe."

No entanto, a Rússia tinha seus interesses e continuava a agressão. Um exemplo muito conhecido é quando o principal canal de televisão estatal da Rússia, Primeiro Canal, entrevistou uma mulher ucraniana com uma história de romper o coração. A mulher disse que "tinha testemunhado a execução pública de um menino de 3 anos de idade, que foi crucificado na praça principal da cidade de Slovyansk no leste da Ucrânia". "A cidade tinha sido um reduto dos separatistas, mas foi retomada pelo exército ucraniano, quando a execução ocorreu", disse a mulher. A mulher acrescentou que "a mãe do menino foi atada a um carro blindado e arrastada até que ela também 
estava morta". Mais tarde, o canal informou que tudo foi uma mentira.

Com a propaganda russa, sofrem também os países europeus. Em uma tentativa de desestabilizar o Ocidente e dividir a Europa, foi usado o breve desaparecimento de uma menina de origem russa na Alemanha que, segundo a Chancelaria da Rússia e a mídia russa, "foi estuprada por um grupo dos imigrantes de Oriente Médio”. Depois da cobertura ampla pela mídia russa dessa história, muitos alemães da origem russa reagiram com raiva, realizando manifestações em várias partes da Alemanha. No entanto, a investigação da polícia da Alemanha revelou que toda a história foi uma mentira e os advogados alemães classificam a reportagem do jornalista russo do Primeiro Canal, que deu início ao escândalo, como incitação ao ódio.

Outro caso aconteceu recentemente. Os jornalistas do canal de televisão russo entrevistaram manifestantes na França. Quando os franceses viram que, ao que eles falavam, estava correndo uma tradução em russo, simplesmente não as reconheceram e expressaram seu desacordo com uso das suas entrevistas com o propósito de propaganda completamente mentirosa.

Como resultado das campanhas de propaganda, está se deteriorando o entendimento mútuo entre os povos e cresce o nível de desconfiança e ódio. O seguinte infográfico apresenta quem são inimigos e amigos para os cidadãos russos. Como é possível ver, os primeiros lugares da lista dos inimigos ocupam os Estados Unidos da América e a Ucrânia.

Figura 1 - Amigos e Inimigos da Rússia

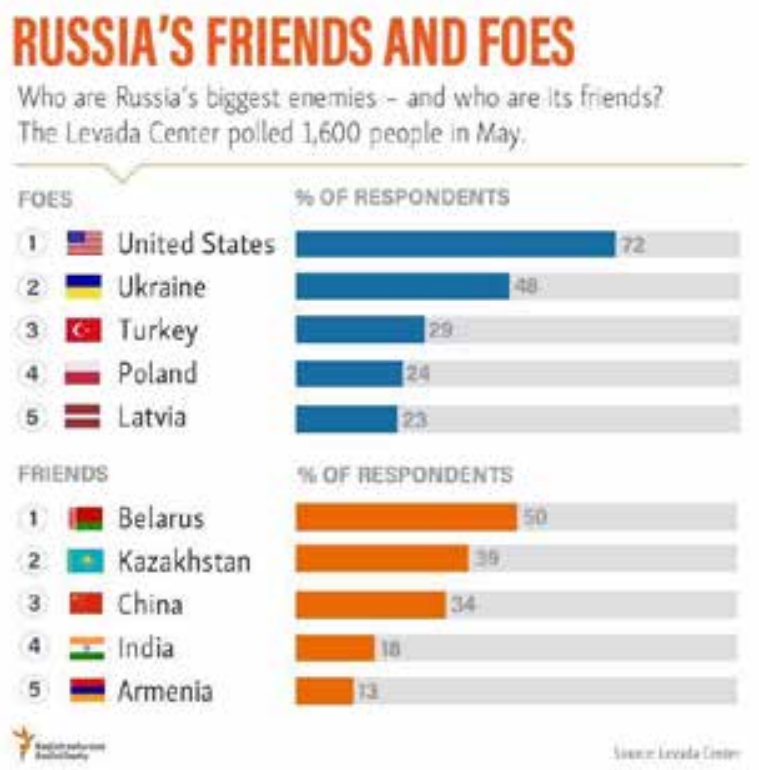

Fonte: <http://www.rferl.org/contentinfographics/russias-friends-andfoes/27774845.html>. Acesso em: 05 mar. 2016.
No entanto, a Ucrânia nem sempre estava na lista dos inimigos de russos. No diagrama abaixo, feito com os dados da Levada Center, podemos ver claramente o momento em que os ucranianos converteram-se de amigos a inimigos corresponde ao período curto após a Revolução das Laranjas na Ucrânia e o início da Revolução de Dignidade, que foi o ponto de partida da presente agressão russa. Como consequência da política externa agressiva russa, os dois povos precisarão anos para restabelecer relações de vizinhos.

\section{$8 \mathrm{Na}$ guerra pela paz}

Com o apoio da comunidade internacional, a Ucrânia continua sua luta pela recuperação da República Autônoma da Criméia, pelo fim da agressão externa militar no Leste da Ucrânia e pelo restabelecimento da paz e da autoridade legítima nos territórios temporariamente ocupados na Ucrânia. Há dois anos, por uma maioria convincente dos votos na Assembleia Geral da Organização das Nações Unidas, foi aprovada a Resolução "Integridade Territorial da Ucrânia” que, em resposta à ocupação da Criméia pela Rússia confirmou a soberania, a independência política, a unidade e a integridade territorial da Ucrânia dentro das suas fronteiras internacionalmente reconhecidas. Em favor da resolução votaram a favor 100 países, contra 11 países, liderados pela Rússia.

Infelizmente, mesmo após o veredito claro da comunidade internacional, a Rússia não se voltou para o Direito das nações civilizadas. Com a sua ocupação ilegal da República Autônoma da Criméia e da cidade de Sebastópol, bem como a invasão militar em Donbass ucraniano, Moscou continua teimosamente a violar o Direito Internacional.

Outro tema imperativo atual e desafiante para comunidade internacional é oproblema de proteção de direitos humanos. Durante os últimos dois anos da ocupação ilegal, a Rússia continua a violar, em grande escala, os Direitos Humanos na Criméia, incluindo do Povo Tártaro da Criméia - o povo nativo da península.

Cabe mencionar os quase 10 mil falecidos entre civis e militares como o resultado da agressão da Rússia, mais de 1,5 milhões de refugiados internos e 800 pessoas desaparecidas.

A Ucrânia exige que a Rússia e os terroristas controlados pela mesma acabem com as violações dos Acor- 
dos de Minsk e garantam o pleno cumprimento das decisões tomadas no âmbito do Grupo de Contato Trilateral.

A realização das eleições nas províncias de Donbass é impossível sem a garantia se sua segurança. A instalação de segurança é impossível sem um cessar-fogo, sem a libertação de presos políticos, sem a retirada das tropas russas e o equipamento militar pesado e sem o acesso completo para os representantes da OSCE a todo o território ocupado, incluindo a parte não controlada da fronteira.

Apesar de todos os problemas de guerra contínua e das consequências econômicas na Ucrânia, temos certeza de que a confiança na ordem mundial vigente pode ser restaurada, desde que atendidos três pontos que julgamos primordiais. Reconhecendo a ONU como um ator chave na manutenção da paz e da segurança internacional, deve-se, em primeiro lugar, empreender esforços para que os objetivos dispostos na Carta de São Francisco sejam respeitados; em segundo, estabelecer mecanismos para inibir violações e, por fim, assegurar que os Estados violadores do Direito Internacional sejam levados à justiça.

Rostyslav Tronenko

Embaixador da Ucrânia no Brasil

\section{Referências}

112. В ООН обеспокоены нарушением прав крымских татар. 2015. Disponível em: <http://112.ua/obshchestvo/ v-oon-obespokoeny-narusheniem-prav-krymskih-tatari-pritesneniy-smi-na-poluostrove-184155.html>. Acesso em: 7 mar. 2015.

112. Випуск n.3. Хроніки Криму. Disponível em: <http:// journal.112.ua/krym-ua/>. Acesso em: 8 mar. 2015.

\section{BRITISH BROADCASTING CORPORATION.} Экономика Крыма в вопросах и ответах. 2014. Disponível em: <http://www.bbc.co.uk/russian/ international/2014/02/140228_crimea_economy_ questions_answers $>$. Acesso em: 6 mar. 2015.

БЕКИРОВА, Гульнара. Страницы крымской истории: Спецпереселенцы не имеют права. Disponível em: <http://ru.krymr.com/content/article/26779236.html >. Acesso em: 4 mar. 2015.

ВОЛЬВАЧ, Петро. Подарунок Хрущова: Як Україна відбудувала Крим. 2011. Disponível em: <http://www. istpravda.com.ua/articles/2011/02/21/26135/>. Acesso em: 4 mar. 2015.
ДЕЛО. Россия начала рейдерский захват отделений ПриватБанка в Крыму. 2014. Disponível em: <http:// delo.ua/finance/rossija-nachala-rejderskij-zahvatotdelenij-privatbanka-v-krymu-234159/>. Acesso em: 8 mar. 2015.

ДЕРЖАВНА казначейська служба України. Виконання Державного бюджету 2013 Річний звіт станом на 2014. Disponível em: <http://www.treasury. gov.ua/main $/$ uk/doccatalog/list? currDir $=212666>$. Acesso em: 7 mar. 2015.

ДЕРЖАВНА служба статистики України. Автономна Республіка Крим. Дані демографічного паспорту територіï. Disponível em: <http://database.ukrcensus. gov.ua/Mult/Dialog/statfile1_c_files/pasport1.htm?1>. Acesso em: 6 mar. 2015.

КРЫМ ИНФОРМ. “Черноморнебтегаз" увеличил добъиу в 2014-м на 21\%. 2015. Disponível em: <http://www.cinform.info/news/id/17483 >. Acesso em: 9 mar. 2015.

КРЫМСТАТ. Статистическая информация Геограбическая структура внешней торговли товарами Республики Крым за 1996-2013 годы. Disponível em: <http://gosstat.crimea.ru/ukgvesi.php\#_ geoi>. Acesso em: 6 mar. 2015.

MIHICTЕРСТВО закордонних справ України. Брифінг в МЗС України. 2014. Disponível em: <http:// mfa.gov.ua/ua/press-center/briefing/1211-brifing-vmzs>. Acesso em: 7 mar. 2015.

MIНICTEРСТВО закордонних справ України. Брифінг в МЗС України. 2014. Disponível em: <http:// mfa.gov.ua/ua/press-center/briefing/1212-brifing-v-mzs >. Acesso em: 7 mar. 2015.

МИНИСТЕРСТВО экономического развития Республики Крым. Республика Крым: Макроэкономическое обозрение за 2014 год. Disponível em: <http://crbc.pro/file/98/cd/98cdcalb329a-4a99-a197-a35c5903297d >. Acesso em: 7 mar. 2015.

НОВОСТИ КРЫМА. Рьночная торговля в Крыму парализована. 2015. Disponível em: <http://news. allcrimea.net/news/2015/1/6/rynochnaya-torgovlya-vkrymu-paralizovana-28754/>. Acesso em: 8 mar. 2015.

ОБОЗРЕВАТЕЛЬ. История Крыма: чей на самом деле полуостров. 2014. Disponível em: <http://obozrevatel. com/politics/93174-istoriya-kryima-chej-na-samomdele-poluostrov.htm>. Acesso em: 3 mar. 2015.

ПОРТАЛ Право України. Розділ 10. Автономна Республіка Крим: Конституиія України. Disponível em: <ttp://pravo-ukraine.org.ua/resyrsi/kz/konstitutsiyaukrajini/rozdil-10-avtonomna-respublika-krimkonstitutsiya-ukrajini>. Acesso em: 5 mar. 2015. 
РБК-Україна. Анексія Криму: найцинічніша зрада в історії України, Порошенко. 2014. Disponível em: $<$ http://www.rbc.ua/ukr/news/politics/anneksiyakryma---samaya-tsinichnaya-izmena-v-istoriiukrainy--18092014173000>. Acesso em: 3 mar. 2015.

СЛОВО I ДІЛО. Джемілєв розкритикував росіян $і$ назвав кримський референдум абсурдом. 2015. Disponível em: <http://www.slovoidilo.ua/ news/1770/2014-04-01/dzhemilev-raskritikovalrossiyan-i-nazval-krymskij-referendum-absurdom. html>. Acesso em: 7 mar. 2015.

СЛОВО І ДІЛО. Залежність Криму від материкової України (інфограбіка). 2015. Disponível em: <http:// www.slovoidilo.ua/articles/8017/2015-03-03/zavisimostkryma-ot-materikovoj-ukrainy-infografika.html $>$. Acesso em: 7 mar. 2015.

СОЦИАЛИСТИЧЕСКОЕ народное хозяйство Крымской области (1945-1970). Симферополь. 1980.

ТИЖДЕНЬ. Кримський депутат: АРК отримує 66\%, а Севастополь 80\% дотацій з держбюджету України. 2014. Disponível em: <http://tyzhden.ua/News/103273>. Acesso em: 6 mar. 2015.

ТИЩЕНКО, Юлія. Народження Кримської Автономії: Як це сталося одинадцять років тому. Disponível em: $<$ http://cidct.info/uk/studii/5-6/10.html $>$. Acesso em: 5 mar. 2015.

УКАЗ Президиума Верховного Совета СССР О передаче Крымской области из состава РСФСР в состав УССР. Ведомости Верховного Совета СССР. $n$. 4, p. 798, 9 mar. 1954.

УКРАЇНА СЬОГОДНІ. Каталог провідних підприємств України: Автономна Республіка Крим. Disponível em: <http://www.rada.com.ua/ukr/ RegionsPotential/Crimea/>. Acesso em: 6 mar. 2015.
УКРАИНСКИЙ банковский портал. Убытки от российской оккупации Крыма оценили в 1 триллион 80 миллиардов гривен. 2014. Disponível em: <http://banker.ua/bank_news/ govregulations/2014/12/19/1180472167/ubytki-otrossijskoj-okkupacii-kryma-ocenili-v-1-trillion-80milliardov-griven/>. Acesso em: 9 mar. 2015.

ФАИЗОВ, Сагит. Поминки: ты в контексте взаимоотношений Руси: России с Золотой Ордой и Крымским юртом. Доклад на Круглом столе татарской общественности «Золотая Орда: исторические параллели», организованном Фондом Развития Мусульманских Народов .2000. Disponível em: <http:// www.mtss.ru/?page=tyish $>$. Acesso em: 3 mar. 2015.

ФАКТИ ICTV. История Крыма: был ли полуостров когда-то российским? 2014. Disponível em: <http:// fakty.ictv.ua/ru/index/read-news/id/1505956>. Acesso em: 4 mar. 2015.

ЧАУШ, Алсу. Крым: за год настроения изменились от эйфории до разочарования и апатии. 2015. Disponível em: $\quad<$ http://ru.krymr.com/content/article/26877236. html>. Acesso em: 7 mar. 2015.

ЧУМАК, Василь. Як Крим увійшов до складу УРСР. Міф про царський подарунок Хрущова. 2014. Disponível em: <http://www.day.kiev.ua/uk/article/ istoriya-i-ya/yak-krim-uviyshov-do-skladu-ursr $>$. Acesso em: 4 mar. 2015.

MILLS, Laura; DAHLBURG, John-Thor. Change of leadership in Crimea means property grab. Associated Press. 2014. Disponível em: <http://www.utsandiego. $\mathrm{com} /$ news $/ 2014 / \mathrm{dec} / 22 /$ change-of-leadership-incrimea-means-property-grab/>. Acesso em: 8 mar. 2015.

NEIL, MacFarquhar. Seizing Assets in Crimea: from shipyard to film studio. 2015. Disponível em: <http:// www.nytimes.com/2015/01/11/world/seizing-assetsin-crimea-from-shipyard-to-film-studio.html?_r=1>. Acesso em: 9 mar. 2015 